\title{
Genetic diversity and structure analysis of Croatian garlic collection assessed by SSR markers
}

\author{
Danijela Poljuha $^{1, *}$, Mario Franic ${ }^{1,2}$, Ines Kralj ${ }^{1}$, Tim Weber ${ }^{1, \dagger}$, Zlatko S̆atovic ${ }^{2,3}$, \\ Dean Ban ${ }^{1,2}$, Nina Toth ${ }^{3}$, Gvozden Dumičićc ${ }^{4}$,Snježana Kereša ${ }^{3}$, \\ Camila Pinto da Cunha ${ }^{5, t+}$, Smiljana Goreta Ban ${ }^{1,2}$
}

\begin{abstract}
${ }^{1}$ Department of Agriculture and Nutrition, Institute of Agriculture and Tourism, Karla Huguesa 8, 52440 Poreč, Croatia ${ }^{2}$ Centre of Excellence for Biodiversity and Molecular Plant Breeding (CoE CroP-BioDiv), Svetošimunska cesta 25, 10000 Zagreb, Croatia ${ }^{3}$ University of Zagreb Faculty of Agriculture, Svetošimunska cesta 25, 10000 Zagreb, Croatia

${ }^{4}$ Department of Applied Sciences, Institute for Adriatic Crops and Karst Reclamation, Put Duilova 11, 21000 Split, Croatia ${ }^{5}$ Department of Genetics, Evolution, Microbiology and Immunology, Institute of Biology, University of Campinas (UNICAMP), Campinas, SP 13083-862, Brazil
\end{abstract}

\begin{abstract}
This study examines genetic diversity and structure of a Croatian garlic germplasm collection using 13 simple sequence repeat (SSR) markers. A total of 71 alleles were observed across 64 accessions representing 3 Croatian regions (Istria, Dalmatia and continental Croatia) and 16 foreign landraces, with an average of 5.46 alleles per locus. Among the 80 accessions analysed, 61 distinct multilocus genotypes (MLG) were identified, of which 51 represented unique genotypes and the remaining accessions were divided into 10 MLG groups, comprising potential duplicates or redundant genotypes. Model-based Bayesian and hierarchical UPGMA clustering approaches revealed five major groups within the collection which partially correlated with geographical origin. The analysis of molecular variance (AMOVA) showed that the majority $(87.71 \%)$ of the total molecular diversity is within the Croatian groups of accessions, even though a significant share (12.29\%) of diversity derived from genetic diversity among groups. These results support regional structuring, as well as the existence of significant diversity within local populations. This study is the first comprehensive report on an extensive evaluation of genetic resources of garlic maintained by Croatia with the aim of setting the course for future preservation strategies with particular emphasis on the value of diversity in the context of climate change both on macro and micro levels.
\end{abstract}

Keywords: collections management, garlic, genetic diversity, genetic structure, plant genetic resources, SSR

Abbreviations: AFLP, amplified fragment length polymorphism; AMOVA, analysis of molecular variance; EST, expressed sequence tags; MLGs, multilocus genotypes; RAPD; random amplified polymorphic DNA; SSR, simple sequence repeat.

\section{INTRODUCTION}

Garlic (Allium sativum L.) is a valuable crop and one of the oldest-known horticultural species. It has been used as a condiment, food and medicinal plant since ancient times (Ipek et al., 2005). The production of garlic in 2018 reached 28,494,130 metric tons, with China being the largest producer and accounting for almost $80 \%$ of

\footnotetext{
${ }^{\dagger}$ Current address: Department of Molecular Life Sciences, University of Zurich,

Winterthurerstrasse 190, CH-8057 Zurich, Switzerland

${ }^{\dagger}$ Current address: Postdoctoral fellow, Department of Plant \& Environmental Sciences,

Weizmann Institute of Science, Rehovot 7610001, Israel

*Corresponding author.

e-mail: danijela@iptpo.hr; dpoljuha@gmail.com (Danijela Poljuha)
} 
the world production (FAOSTAT, 2018). Its centre of origin is considered to be in Central Asia (Kyrgyzstan, Tajikistan, Turkmenistan and Uzbekistan) (Hong and Etoh, 1996) with Allium longicuspis proposed to be its wild ancestor (Egea et al., 2017). It belongs to the genus Allium whose recent classification is mostly based on nuclear ribosomal DNA sequences involving the internal transcribed spacer region and includes $>800$ species in 15 subgenera and $>70$ sections (Li et al., 2010; Friesen et al., 2020). Two regions with broad species diversity are from the Mediterranean basin to Central Asia and North-West of America (Fritsch and Friesen, 2002; Li et al., 2010).

Garlic is diploid $(2 n=16)$ and asexually (vegetative) propagated species, primarily from cloves due to obligatory apomixis (Bradley et al., 1996), although a few fertile types had been reported (Etoh et al., 1988). Therefore, clonal selection is the method of choice for garlic breeding. Sexual reproduction and fertility are impaired among commercial cultivars (GarcíaLampasona et al., 2003), relying solely on mutations (spontaneous or induced), somaclonal variation and genetic transformation. Vegetative reproduction usually assures crop uniformity, but in garlic, there is a great degree of diversity in phenotypic traits, as well as in some agronomic traits such as drought tolerance and other stress responses (Bradley et al., 1996; Stavělíková et al., 2008). Large genetic diversity has been observed in garlic clones that are cultivated around the world and also in collected non-cultivated garlic accessions found in nature (Maass and Klaas, 1995; Bradley et al., 1996; Volk et al., 2004). Classification of cultivars based on morphological traits is difficult due to a wide variation in clove number, colour and size within the same cultivar, varying further phenotypically under different agro-climatic conditions, despite the lack of sexual reproduction.

Conservation of garlic genetic resources is important as such collections present a source of traits with potential economic value. A large number of garlic genetic resources are maintained in gene banks, which are a source of variability and present an opportunity for genetic research and breeding programs. Two main strategies for preserving garlic collections are field maintenance and cryopreservation, each of them having their benefits and drawbacks, but for long-term preservation cryopreservation generally becomes less costly than field culture after 8-13 years (Keller et al., 2013). Maintenance of field collections is expensive and laborious and demands equipment and consumables. Hence, characterisation and evaluation of accessions require a combination of agro-morphological traits and molecular markers to help decision-making in minimising the number of accessions and maximising the genetic diversity. Molecular studies of garlic are mainly focused on the analysis of genetic diversity of cultivated garlic clones, mostly studied through the use of several molecular marker techniques, such as random amplified polymorphic DNA (RAPD) (Maass and Klaas, 1995; Paredes et al., 2008), amplified fragment length polymorphism (AFLP) (García-Lampasona et al., 2003; Volk et al., 2004; Ipek et al., 2005, 2006) and isozymes (Ipek et al., 2003). These techniques are preferential in discriminating garlic taxonomy because they are not affected by environmental conditions, which is an issue with morphological traits.

Simple sequence repeats (SSRs) or microsatellites have been extensively used in the analysis of genetic diversity and population genetic studies on many plant species, including garlic (Ma et al., 2009; Wang et al., 2010; Zhao et al., 2011; Jo et al., 2012; Cunha et al., 2014; Ipek et al., 2015; Barboza et al., 2018; Kumar et al., 2019). Besides next-generation sequencing techniques and high-throughput genotyping-by-sequencing (GBS) approaches, SSR markers are still preferred and intensively used due to genome abundance, high polymorphism, co-dominance, high reproducibility, low cost and transferability in laboratories (Wang et al., 2010). Barboza et al. (2018) developed 110 SSR markers from expressed sequence tags (EST) and summarised in total 312 previously reported genomic and EST SSR markers in garlic species (Ma et al., 2009; Lee et al., 2011; Cunha et al., 2012; Chand et al., 2015; Ipek et al., 2015; Liu et al., 2015). However, their usage has been limited by the large $(15.9 \mathrm{Gbp} / 1 \mathrm{C})$ and duplicated genome that result, in some cases, in more than two alleles per SSR locus (Ipek et al., 2008; Ma et al., 2009; Egea et al., 2017; Peška et al., 2019). In the Adriatic region, garlic has been grown since ancient times (Dumičić et al., 2013). Six Croatian garlic landraces (traditional cultivars or varieties) - Brgudski ozimi sinonim Benkovački, Cerićki ozimi, Istarski crveni, Podravski ozimi, Slavonski ozimi and $\check{S}$ okac - are registered in the EU Plant Variety Database (v.3.2.1).

The objective of this study was to assess the genetic diversity and structure of the Croatian garlic collection comprising 64 accessions from 3 Croatian regions (Istria, Dalmatia and continental Croatia) and 16 foreign landraces using SSR markers. To our knowledge, this is the first attempt to extensively evaluate garlic accessions from Croatia. Obtained results would give better insight on garlic genetic resources, and thus support the effective and sustainable management of Croatian collections.

\section{MATERIAL AND METHODS}

\section{Plant material}

A total of 80 accessions maintained as a working collection of the Institute of Agriculture and Tourism, Poreč, Croatia, were evaluated, of which 64 accessions were originated from 3 Croatian regions and 16 from abroad. Some of the Croatian accessions evaluated here are already a part of the working Collection of Vegetables of the National Program for the Conservation and Sustainable Use of Plant Genetic Resources for Food and Agriculture. The information on the 
accessions included in the national collection (CPGRD ID in Table S1 in Supplementary Materials) is available in the Croatian Plant Genetic Resources Database: https://cpgrd.hapih.hr/.

Garlic accessions used in the analysis are given in Table S1 in Supplementary Materials. Eleven of sixteen foreign landraces were sourced from the United States Department of Agriculture (USDA, Pullman, WA) through the Germplasm Resources Information Network (GRIN) in 2017. Three accessions were sourced from Plant Genetic Resources Network held by Embrapa Genetic Resources and Biotechnology, Brazil. The remaining two foreign accessions were obtained from the nursery (Semenarna Ljubljana) or directly from the breeder (see Table S1 in Supplementary Materials; IPTPO ID: AGRE11 and IPT189).

\section{SSR genotyping}

Total genomic DNA was extracted from fresh young leaves of a single individual plant $(100 \mathrm{mg})$ per accession, using the commercial kit PureLink ${ }^{\circledR}$ Plant Total DNA Purification Kit (Invitrogen), in accordance with the manufacturer's instructions.

Thirteen SSR markers [GB-ASM-040, GBASM-053, GB-ASM-059, GB-ASM-072, GB-ASM-080 (Ma et al., 2009), Asa14 (Cunha et al., 2012) and As739, As623, As2655, As96, As449, As6389 and As5944 (Ipek et al., 2015)] were used for genotyping (Table 1) by following the optimised procedures described in Ma et al. (2009) and Ipek et al. (2015). Forward SSR primers were end-labelled with 6FAM fluorophore. The amplified fragments were run on an ABI 3730XL DNA analyser (Applied Biosystems, Foster City, CA, USA) and the results were analysed using GeneMarker ${ }^{\circledR}$

Table 1. Allelic diversity of 13 microsatellite loci scored in 80 garlic accessions.

\begin{tabular}{|c|c|c|c|c|}
\hline No. & Locus & Repeat motif & Size range & $N_{a}$ \\
\hline 1 & Asa14 & $(\mathrm{GT})_{7}$ & $221-243$ & 5 \\
\hline 2 & GB-ASM-040 & $(\mathrm{AC})_{6},(\mathrm{AC})_{14}-(\mathrm{AT})_{5}$ & $253-283$ & 6 \\
\hline 3 & GB-ASM-053 & $(\mathrm{CA})_{15},(\mathrm{AC})_{8}$ & $156-214$ & 8 \\
\hline 4 & GB-ASM-059 & $(\mathrm{TG})_{11},(\mathrm{TG})_{5}$ & $264-295$ & 5 \\
\hline 5 & GB-ASM-072 & $\begin{array}{l}(\mathrm{TA})_{7}^{-} \\
(\mathrm{TG})_{5} \mathrm{GC}(\mathrm{GT})_{9} \mathrm{~T}(\mathrm{TG})_{8}\end{array}$ & $161-273$ & 6 \\
\hline 6 & GB-ASM-080 & $(\mathrm{CCG})_{5}$ & $142-155$ & 4 \\
\hline 7 & AS739 & $(\mathrm{AGC})_{10}$ & $196-212$ & 6 \\
\hline 8 & AS623 & $(\mathrm{GCT})_{6}$ & $289-292$ & 2 \\
\hline 9 & AS2655 & $\left(\mathrm{AGAAA}_{5}\right.$ & $239-262$ & 6 \\
\hline 10 & AS96 & $(\mathrm{AACGGC})_{4}$ & $123-141$ & 5 \\
\hline 11 & AS449 & $(\mathrm{AGATGG})_{5}$ & $195-221$ & 6 \\
\hline 12 & AS6389 & $(\mathrm{AGCCTG})_{5}$ & $100-235$ & 5 \\
\hline \multirow[t]{2}{*}{13} & AS5944 & $(\mathrm{AC})_{28}$ & $159-231$ & 7 \\
\hline & Average & & & 5.46 \\
\hline
\end{tabular}

Software V2.7.0 (SoftGenetics, USA) and 400HD ROX ${ }^{\mathrm{TM}}$ dye-labelled internal size standard marker. SSR peak estimates were determined using inbuilt software on pre-set settings. Each peak was individually evaluated. Where more than two alleles (peaks) were apparent, their pattern was cross-examined with other available samples to determine their unique descriptive allelic values. To eliminate the possibility of error, all samples in which the appearance of multiple peaks was detected were analysed several times. Multiple peaks can be addressed by picking two 'main' peaks to allow further analysis of co-dominant markers (Ma et al., 2009) or by treating SSRs as dominant markers and recording the presence or absence of all specific alleles (Pan, 2006; Arroyo et al., 2010; Trapnell et al., 2011; Wang et al., 2014; Meena et al., 2020) to avoid bias in the elimination of specific and reproducible peaks. We used the latter approach in genetic structure analysis.

\section{Data analysis}

Alleles from each microsatellite marker were scored as present (1) or absent (0) to create a binary matrix. After the identification of accessions sharing the identical multilocus genotype, replicates originating from the same region were removed from the dataset to calculate molecular diversity parameters. Molecular diversity was inferred by distinct clones $\left(\mathrm{N}_{\mathrm{g}}\right)$, genotypic (clonal) richness $\left(\mathrm{N}_{\mathrm{gr}}\right)$, number of private genotypes [genotypes found exclusively in a particular group of accessions] $\left(\mathrm{N}_{\mathrm{pr}}\right)$, private genotypic (clonal) richness $\left(\mathrm{N}_{\mathrm{par}}\right)$, percentage of polymorphic markers and Shannon's information index (Shannon and Weaver, 1949; Lewontin, 1972). $\mathrm{N}_{\mathrm{gr}}$ and $\mathrm{N}_{\mathrm{par}}$ were defined as the number of distinct genotypes and the numbers of private genotypes independent of the sample size, respectively, and they were calculated using the rarefaction method of Hurlbert (1971) as described by Lazović et al. (2018).

Pairwise distances between 80 accessions were calculated using Dice's coefficient (Dice, 1945), and a UPGMA tree based on Dice's distance matrix was constructed. Statistical support of the branches was tested with a bootstrap analysis using 1,000 replicates (Felsenstein, 1985). The calculations were made using PAST v4.01 (Hammer et al., 2001).

The assessment of the genetic structure was performed using STRUCTURE v2.3.4 (Pritchard et al., 2000) and BAPS v6.0 (Corander et al., 2003), including 61 distinct multilocus genotypes (MLGs). Thirty runs of STRUCTURE were done by setting the number of clusters from 1 to $11(K=1-11)$ on the Isabella computer cluster at the University of Zagreb, University Computing Centre (SRCE). Each run consisted of a burn-in period of 200,000 steps followed by $10^{6} \mathrm{MCMC}$ (Monte Carlo Markov Chain) replicates assuming admixture model and correlated allele frequencies. No prior information was used to define the clusters. The choice of the most likely number of clusters $(K)$ was carried out by comparing the average 
estimates (and standard deviations) of the likelihood of the data, $\ln [\operatorname{Pr}(\mathrm{X} \mid K)]$, for each value of $K$ as well as by calculating an ad hoc statistic $\Delta K$ (Evanno et al., 2005) as implemented in STRUCTURE HARVESTER v0.6.94 (Earl and Vonholdt, 2012). Runs were clustered and averaged using CLUMPAK (Kopelman et al., 2015). BAPS was run with the maximal number of clusters $(K)$ set to 10 and each run was replicated 30 times. The best value of $K$ was estimated using the log marginal likelihood values of the best partitions and the distribution of posterior probabilities for different $K$ values. Results of the mixture analysis were used as input for population admixture analysis (Corander and Marttinen, 2006) with default settings.

The analysis of molecular variance (AMOVA; Excoffier et al., 1992) was used to partition the total molecular variance among and within groups of accessions originating from the three Croatian regions and abroad. The variance components were tested using 10,000 permutations in Arlequin v3.5.2.2 (Excoffier and Lischer, 2010). Pairwise comparisons between groups that were examined with AMOVA resulted in $\varphi S T$ values, which were equivalent to the proportion of the total variance that was partitioned between the two groups.

\section{RESULTS}

Thirteen SSR markers were selected for this study (Table 1). We found 1-5 alleles per locus for each accession. Overall, 71 alleles were detected with a mean of 5.46 alleles per locus. The number of alleles per locus ranged from two at AS623 to eight at GB-ASM-053 (Table 1).

Among the 80 accessions evaluated, we identified 61 distinct MLGs, of which 51 represented unique genotypes. The remaining accessions were divided in 10 MLG groups, comprising potential duplicates or redundant genotypes. Group size ranged from two to seven accessions per group.

Our molecular diversity study of garlic accessions revealed a total of 48 distinct genotypes in the group of 64 Croatian accessions, while all of the 16 foreign accessions were distinct genotypes (Table 2). Croatian

Table 2. Molecular diversity of 80 garlic accessions.

\begin{tabular}{llccccccc}
\hline No & Origin & $n$ & $N_{g}$ & $N_{g r}$ & $N_{p r}$ & $N_{p a r}$ & $\% P$ & $I$ \\
\hline 1 & Croatia & 64 & 48 & - & 45 & - & 84.51 & 0.508 \\
\multirow{2}{*}{1.1} & $\begin{array}{l}\text { Continental } \\
\text { Croatia }\end{array}$ & 16 & 13 & 13.00 & 11 & 11.00 & 64.79 & 0.493 \\
1.2 & Istria & 22 & 18 & 13.61 & 17 & 12.88 & 67.61 & 0.412 \\
1.3 & Dalmatia & 26 & 19 & 12.66 & 16 & 10.43 & 70.42 & 0.420 \\
2 & Foreign & 16 & 16 & 16.00 & 13 & 13.00 & 94.37 & 0.626 \\
\hline & Total & 80 & 61 & & & & & \\
\hline
\end{tabular}

$n$ is the number of accessions; $N_{g}$ is the number of distinct genotypes; $N_{g r}$ is the genotypic richness; $N_{p r}$ is the number of private genotypes;

$N_{p a r}$ is the private genotypic richness; $\% P$ is the percentage of polymorphic loci; $I$ is the Shannon's information index. and foreign sets shared three genotypes (Figure 1; accessions P1S02/P4S75, P3S40/P4S70 and P4S78/ P1S01/P3S47/P3S48/P3S52/P3S57/P3S59). Within the group of Croatian accessions, the highest number of distinct genotypes (19) was observed in the group originating from Dalmatia. The lowest number of distinct genotypes (13) was found in accessions from continental Croatia. However, the values of genotypic richness, i.e. the number of genotypes independent of sample size was relatively similar across regions, ranging from 12.66 to 13.61. The Croatian region of Istria had the highest share of private genotypes, as well as the highest private genotypic richness (Table 2), while the region of continental Croatia showed the highest Shannon's information index.

A total of 48 distinct genotypes were identified in the Croatian set of accessions. The genotypes within groups (from one or more Croatian regions, but not among foreign accessions) were counted as one distinct genotype; e.g. accessions P1S02 (MLG G06) and P3S40 (MLG G09) are not considered as distinct genotypes (Table S1 in Supplementary Materials). The number of private genotypes attributed to the Croatian regions refers to all genotypes, except for foreign accessions (Table S1 in Supplementary Materials). The higher percentage of polymorphic loci and Shannon's index of the foreign set of accessions reflected the geographically distant origins.

UPGMA tree based on Dice's distance matrix was constructed to assess the relationships among accessions (Figure 1). Five main clusters (A-E) and two separate lineages (P2S30 and P4S77-SYR) were identified. Clusters B, C and E were supported with bootstrap values $>50 \%$.

The assessment of the genetic structure was performed on 61 distinct MLGs using STRUCTURE and BAPS softwares. The most probable number of clusters $(K)$ was inferred by the ad hoc statistic $\Delta K$ based on the rate of change in the log probability of data between successive $K$ values (Evanno et al., 2005). The highest $\Delta K$ value was detected at $K=3(\Delta K=391.14)$ followed by $K=4(\Delta \mathrm{K}=21.18)$ and $K=5(\Delta K=9.37)$, whereas the highest average estimate of the likelihood of the data, $\ln [\operatorname{Pr}(\mathrm{X} \mid \mathrm{K})]$, was obtained at $K=5(-944.85)$ (Figure S1 in Supplementary Materials).

As expected, the results obtained by STRUCTURE (Figure 1B) were congruent with the UPGMA tree (Figure 1A). At $K=3$ clusters A and B corresponded to the UPGMA clustering, whereas cluster $\mathrm{C}$ included the UPGMA clusters $\mathrm{C}-\mathrm{E}$. At $K=4$, cluster $\mathrm{C}$ splitted into UPGMA clusters $\mathrm{C}$ and $\mathrm{D}$, and finally, at $K=5$, cluster D splitted into UPGMA clusters D and E. Therefore, STRUCTURE and UPGMA clustering were in accordance. Two separate lineages (P2S30 and P4S77-SYR) observed in the UPGMA tree represented accessions of mixed ancestry (Figure 1B).

The presence of distinct clusters among accessions was further evaluated using a Bayesian approach as implemented in BAPS. The partition with the highest log 
marginal likelihood $(-1,305.93)$ consisted of five clusters that were highly congruent with both the UPGMA tree clustering and the results of STRUCTURE at $K=5$ (Figure 1C).

Most accessions (38/80) were grouped into cluster A, followed by cluster B (24/80), and clusters C-E (with 8, 8 and 2 accessions, respectively) (Figure 1). Accessions from the Istria region prevailed in cluster A (18 of 38),

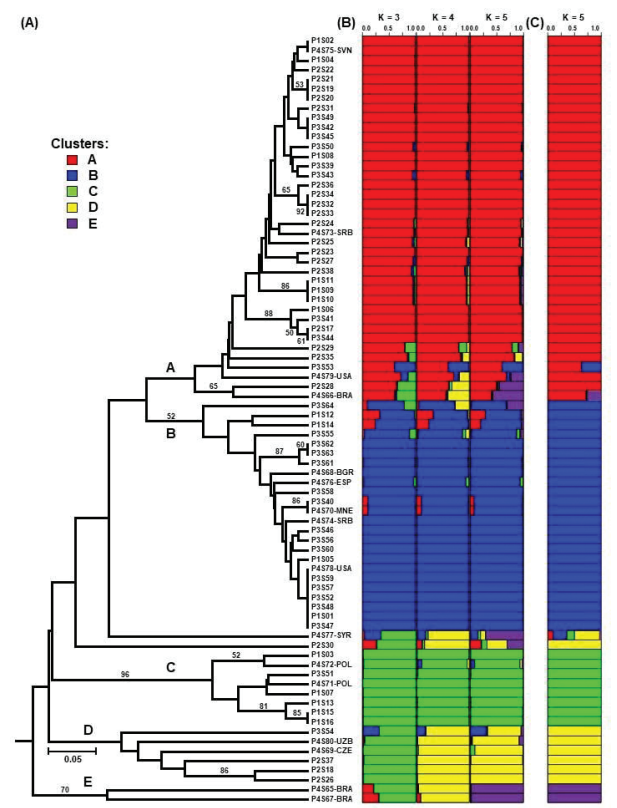

Figure 1. UPGMA tree (A) based on SSR marker data of 80 garlic accessions and its proportion of membership in each cluster as defined by STRUCTURE (B) and BAPS (C). Region of origin of each accession is indicated as follows: P1 - continental Croatia, P2 - Istria, P3 Dalmatian and P4 - foreign (followed by three-letter country codes). Bootstrap support values $>50 \%$ of 1,000 replicates are given above branches. Each accession is represented by a single horizontal rectangle divided into colours. Each colour represents one cluster, and the length of the coloured segments shows the estimated proportion of membership in that cluster. SSR, simple sequence repeat. followed by those from Dalmatia (9) and continental Croatia (7). Only four foreign accessions were grouped in this cluster. Accessions from Dalmatia grouped mostly into cluster B (15/24), together with four accessions from continental Croatia and five foreign accessions. Eight accessions grouped into cluster $\mathrm{C}$, of which five were from continental Croatia, one from Dalmatia and two foreign accessions. Cluster D comprised three foreign and four Istrian accessions, as well as a Dalmatian one, whereas two foreign accessions grouped into cluster E. An accession from Istria and a foreign accession (Syria) assigned to cluster D showed highly admixed ancestry and formed separate lineages on the UPGMA tree.

Accessions from Slovenia and Serbia grouped in cluster A, including one accession from the USA and one from Brazil. Cluster B comprised accessions from Balkan countries (Bulgaria, Montenegro and Serbia), Spain and the USA. Accessions from the Czech Republic and Uzbekistan grouped in cluster D, whereas two Brazilian accessions formed the cluster E.

The AMOVA was used to partition the total molecular diversity among and within groups of accessions originating from the three Croatian regions and abroad (Table 3).

AMOVA showed that approximately $97.25 \%$ of the total genetic diversity was attributable to differences among accessions within the two origin groups resulting in a non-significant $\varphi_{S T}$ value (Table $3(\mathrm{~A})$ ). However, the partition of the total genetic diversity among and within three Croatian regions revealed that a significant $(p<0.0001)$ proportion of total variation $(12.29 \%)$ was due to genetic differences of accessions among the three Croatian regions (Table 3(B)). The same was true in AMOVA that included the accessions from three Croatian regions and a group of foreign accessions (Table 3(C)) although the proportion of total variation (8.89\%) attributable to the among-group component was somehow lower, but still highly significant $(p<0.0001)$.

The pairwise comparisons between the four groups of accessions revealed that the partition between the group of foreign accessions (P4) and those from continental Croatia (P1) was non-significant as it was between the Dalmatian group (P3) and foreign

Table 3. AMOVA for the partition of the total molecular diversity between and within Croatian and foreign garlic accessions (A), among and within three Croatian regions (B) and among and within three Croatian regions including foreign accessions as a fourth group.

\begin{tabular}{llccccc}
\hline Analysis & Source of variation & $\mathrm{df}$ & Variance components & \% total variation & $\varphi$-statistics & $P(\varphi)$ \\
\hline \multirow{2}{*}{ (A) } & Among groups & 1 & 0.244 & 2.75 & 0.027 & 0.099 \\
& Within groups & 62 & 8.639 & 97.25 & & \\
\hline \multirow{2}{*}{ (B) } & Among groups & 2 & 1.023 & 12.29 & 0.123 & $<0.0001$ \\
& Within groups & 47 & 7.304 & 87.71 & & \\
\hline \multirow{2}{*}{ (C) } & Among groups & 3 & 0.790 & 91.11 & 0.089 & $<0.0001$ \\
& Within groups & 62 & 8.090 & & \\
\hline
\end{tabular}

AMOVA, analysis of molecular variance. 
accessions (P4) (Table 4). However, all the partitions including the Istrian group of accessions (P2) were significant, and the highest $\varphi_{S T}$ was obtained when analysing the partition between the Istrian (P2) and Dalmatian (P3) groups.

\section{DISCUSSION}

The cultivation and use of garlic are a part of the Croatian tradition, and each region or village has its local landraces preserved for generations (Dumičić et al., 2014). In the last decades, significant efforts have been made to collect and characterise national genetic resources to ensure their long-term conservation in ex situ collections, and thus, their sustainable management. The Institute of Agriculture and Tourism (IPTPO) collection was established in 2014 and is continually expanded ever since. A molecular characterisation of the collection has not been carried out so far, and the available published data are sparse (Poljuha et al., 2018).

In this study, we aimed to molecularly characterise the current Croatian garlic collection and to assess its genetic diversity and structure. We genotyped 64 accessions originating from three Croatian regions, along with 16 introduced cultivars, using 13 polymorphic SSR markers. The study revealed a total of 48 distinct genotypes in the group of Croatian accessions, while all analysed foreign accessions were distinct genotypes. The diversity of the latter set (also confirmed by a higher percentage of polymorphic loci and Shannon's index) was expected because the foreign garlic materials analysed in the present study were intentionally selected to broaden genetic variation in the sample set. They were obtained from the collection of the USDA (Pullman, WA, USA) and chosen to represent 7 out of 10 different phylogenetic groups identified in previous AFLP-based diversity analysis of garlic (Ipek et al., 2003). In addition, within this set of samples, we analysed three accessions from the Brazilian collection

Table 4. AMOVA's pairwise $\varphi_{S T}$ values among groups of garlic accessions.

\begin{tabular}{|c|c|c|c|c|c|}
\hline $\begin{array}{l}\text { Group of } \\
\text { accessions }\end{array}$ & Region & P1 & $\mathrm{P} 2$ & P3 & P4 \\
\hline P1 & $\begin{array}{l}\text { Continental } \\
\text { Croatia }\end{array}$ & & * & ns & ns \\
\hline P2 & Istria & 0.103 & & $* * *$ & $* *$ \\
\hline P3 & Dalmatia & 0.049 & 0.189 & & ns \\
\hline P4 & $\begin{array}{l}\text { Foreign } \\
\text { accessions }\end{array}$ & -0.006 & 0.115 & 0.048 & \\
\hline \multicolumn{6}{|c|}{ Below diagonal: pairwise $\varphi_{S T}$ values. } \\
\hline \multicolumn{6}{|c|}{ Above diagonal: $P\left(\varphi_{S T}\right)$. } \\
\hline \multicolumn{6}{|c|}{ AMOVA, analysis of molecular variance; ns, non-significant. } \\
\hline \multicolumn{6}{|c|}{ *Significant at $p<0.05$} \\
\hline \multicolumn{6}{|c|}{$* *$ Significant at $p<0.01$. } \\
\hline \multicolumn{6}{|c|}{$* * *$ Significant at $p<0.001$. } \\
\hline
\end{tabular}

at Embrapa. The diversity of Croatian garlic accessions observed through different parameters was relatively similar across all three regions (Table 1). The most diverse group of Croatian accessions originated from the Dalmatia region, with 19 distinct genotypes, out of the 26 analysed. Although the observed diversity is probably related to the sample size, Dalmatia is a wellknown location of garlic cultivation (Ožanić, 1955; Dumičić et al., 2013), with a few widely distributed and highly valued ecotypes, such as Ljubitovački šarac and Brgudski ozimi. However, the highest genotypic richness and the number of private genotypes were found in the set of accessions from the Istria region, indicating the potential of this area as a valuable source of genetic material for breeding. Genotypic richness could correlate with specific and diverse microclimate conditions in a relatively small area.

In this research, we chose 13 polymorphic SSR markers, developed in previous studies (Ma et al., 2009; Cunha et al., 2012; Ipek et al., 2015) and applied in the analyses of garlic genetic resource collections and germplasms (Zhao et al., 2011; Jo et al., 2012; Cunha et al., 2014; Barboza et al., 2020). The SSR markers revealed considerable genetic diversity among 61 MLGs identified, with Dice's distance ranging from 0.019 to 0.773 , with an average value of 0.346 . Usually, SSR-based methods rely on identifying a maximum of two peaks in an electropherogram, measuring the fluorescence of correctly matched tags for either homozygous or heterozygous individuals. This becomes challenging in species where genome duplication is common. In this study, we observed from one to five peaks on a single SSR marker per accession (Table S2 in Supplemenatry Materials). Moreover, the observed variations in garlic SSR loci could also occur in part as a result of replication slippage (Hosseinzadeh-Colagar et al., 2016). Since we were able to observe clear peaks and other authors also reported more than two alleles per SSR locus in diploid Allium species (Fischer and Bachmann, 2000; Ipek et al., 2008, 2015; Ma et al., 2009; Jo et al., 2012), we disregarded slippage in favour of suggested genome duplication. Even if the number of peaks could be matched, there is no objective method to determine a cut-off value that would accurately describe the actual phylogenetic relationship of the accessions, as confirmed by other molecular methods, breeding programme records or even phenotypic observation. This does not devalue the use of SSR for phylogenetic conclusions if a stringent methodology for recognising peaks is observed. A few authors reported a significant diversity within garlic collections, using both morphological and molecular data (Zhao et al., 2011; García-Lampasona et al., 2012; Chen et al., 2014; Cunha et al., 2014; Barboza et al., 2020). In this study, AMOVA analysis revealed $87.71 \%$ of the total molecular diversity within and $12.29 \%$ among Croatian groups. The same pattern was observed when evaluating the three Croatian regions and a group of foreign accessions. These 
results support regional structuring and the existence of significant diversity within local populations as a consequence of probable ancestral sexual reproduction followed by independent domestication history (Cunha et al., 2014). These values are in accordance with the results of Zhao et al. (2011) and Kumar et al. (2019), who observed similar percentages of variance $(84.4 \%$ and $84.0 \%$, respectively) attributable to within-population differences.

Clustering analysis revealed five main clusters among the 64 Croatian and 16 foreign accessions (clusters A-E, Figure 1). The distinction of clusters based on geographical origin was not clear, mainly due to unknown historical origin of accessions, frequent exchange of propagule material among farmers from different Croatian regions and the vegetative propagation of the species. Istrian garlic accessions were mostly grouped in cluster A and Dalmatian prevailed in cluster $\mathrm{B}$, whereas the accessions from continental Croatia were evenly distributed in clusters A-C (Figure 1A). Since our primary intention was to catalogue the collection and detect duplicate or redundant genotypes, we were especially interested in the closely related samples. With 13 markers used, we detected only 10 MLG groups in 80 analysed samples. All identical and closely related accessions were observed in clusters $\mathrm{A}-\mathrm{C}$, and their grouping was based on geographical origin (e.g. P2S19, P2S20 and P2S21; P2S32, P2S33 and P2S34; P3S42, P3S45 and P3S49; P1S09, P1S10 and P1S11; P1S15 and P1S16; etc.) or traditional ways of plant material exchange in these areas (e.g. P3S40 and P4S70; P3S47, P3S48, P3S52, P3S57, P3S59 and P1S01; etc.).

We also noticed a great diversity among accessions from some narrow geographical areas, such as the Central Istrian Pazin area, where we identified diverse groupings of collected samples. Closely related accessions P2S23, P2S24 and P2S25 grouped in cluster A, together with the Istrian genotype P2S27 with a peculiar morphological and aromatic characteristics. In contrast, two accessions from the same area, P2S18 and P2S37, grouped in cluster $\mathrm{D}$, together with geographically closed P2S26 accession. Such areas with pronounced diversity are a valuable source of plant material for breeding purposes. In this study, we also identified the relationship between some widely distributed and highly valued cultivars, such as 'Ljubitovečki šarac' (accession P3S53), which displayed admixture of two populations with membership shared between clusters A and B (0.63:0.37, respectively).

A few authors have reported a moderate level of correlation between genetic clustering based on SSR markers with geographical origin (Ma et al., 2009; Zhao et al., 2011; Jo et al., 2012; Kumar et al., 2019), whereas other studies reported none (Ipek et al., 2003, 2008; Volk et al., 2004; Paredes et al., 2008; Barboza et al., 2018). Clustering by phenotypic characteristics observed by different authors is also variable (Bradley et al., 1996; García-Lampasona et al. 2010; Ovesná et al., 2014; Ovesná et al., 2015; Barboza et al.,
2020). In our study, accessions were not clustered according to their flowering behaviour (Table S1 in Supplementary Materials). The lack of correlation between morphological variation and marker pattern may originate from the non-association of the markers used for genotyping with phenotypic characteristics but also can be rooted in epigenetic variation in garlic lines, propagated in some regions for centuries. Barboza et al. (2020) observed and explained the discrepancy between the level of genetic and phenotypic variation found in the Argentine garlic collection by studies of Gimenez and García-Lampasona (2018) and Gimenez et al. (2016). They indicated frequent and dynamic epigenetic changes in non-coding and coding regions of the garlic genome, even under normal field-cultivation conditions, in comparison to less frequent genetic changes, as possible causes for the observed discrepancies between molecular and phenotypic variation.

In our analysis, foreign accessions were present in all clusters (Figure 1). Brazilian cultivars 'Chinês Real' (P4S65) and 'Ugarte' (P4S67) formed the genetically most distant cluster E. However, the third Brazilian accession P4S66 (cv. 'Peruano') grouped in cluster A, in a subcluster with accession P2S28 from the Istrian region. All the above-mentioned Brazilian cultivars were previously analysed by SSRs in the study of Cunha et al. (2014) using a set of 130 accessions. In their study, cultivar 'Peruano' formed a separate lineage as the only accession with admixed ancestry. Two Polish accessions (P4S71 and P4S72) grouped in cluster C, whereas accession P4S69 from North Moravia in Czech Republic and P4S80 originated from Uzbekistan grouped in cluster D. Accession P4S80 (UO85) was classified as A. longicuspis L. in the GRIN (USDA) database but in our analysis did not separate from other accessions of A. sativum $\mathrm{L}$. This is in accordance with the study of Ipek et al. (2015) in which accessions of both species were clustered together based on their flowering ability but not on their geographic origin. Volk et al. (2004), who examined the diversity of 211 commercial and federally held accessions maintained by the US National Plant Germplasm System (NPGS), including the clone U085, also report the indistinguishability of $A$. longicuspis and A. sativum.

Our analysis revealed two accessions that formed separate lineage having admixture ancestry - Syrian P4S77 and P2S30 (Figure 1). Accession P4S77 is classified as cv. 'Kisswani' in the GRIN database (USDA) and the cultivar originates from Syria. Accession P2S30 is recorded as cv. 'Music' in the IPTPO collection. It belongs to A. sativum ssp. ophioscorodon, and the hardneck garlic type that produces scapes or flower stalks originates from Italy. This cultivar is characterised by high overwintering ability, increased vigour and high marketable yields (Walters, 2008).

This study confirms the usefulness of SSR genotyping for examination of diversity within garlic collections and provides important information for 
further management of Croatian garlic collection, as well as its relationship to known international garlic cultivars.

\section{CONCLUSIONS}

Garlic is a staple crop present in the Mediterranean culture for hundreds of years. As highly valued vegetative species, it was enjoyed and traded wherever people moved, and it is evident that farmers went through great efforts to select unique varieties. Assessment of genetic diversity and structure of the Croatian garlic germplasm supported regional structuring and the existence of significant diversity within local populations. Genetic differentiation of the accessions based on origin provides insights into the movement of garlic genotypes, as well as ethnological and historical data. This study is the first attempt of a molecular characterisation of collected genetic resources of garlic in Croatia with the aim of setting the course for future preservation strategies with particular emphasis on the value of diversity in the context of climate change both on macro and micro levels.

\section{ACKNOWLEDGEMENTS}

The authors thank curators of Allium sativum collections Barbara Hellier from the United States Department of Agriculture (USDA), Pullman, WA, and Roberto Fontes Vieira from Embrapa Genetic Resources and Biotechnology, Brazil, for providing plant material.

\section{FUNDING}

This research is funded by the Ministry of Agriculture Republic of Croatia through National Program for the Conservation and Sustainable Use of Plant Genetic Resources for Food and Agriculture and the project KK.01.1.1.01.0005 Biodiversity and Molecular Plant Breeding, Centre of Excellence for Biodiversity and Molecular Plant Breeding (CoE CroP-BioDiv), Zagreb, Croatia.

\section{AUTHOR CONTRIBUTIONS}

D. P., Z. Š and S. G. B. worked on conceptualisation, methodology and validation. D. P., M. F., I. K., T. W. and Z. Š. performed formal analysis. D. P., D. B., N. T., G. D., S. K. and C. C. participated in providing the necessary resources. D. P., M. F., I. K., T. W. and S. G. B. curated the data. Z. Š., S. G. B., D. B., D. P. and S. K. contributed to the funding acquisition. D. P., M. F., T. W. and Z. Š. prepared original manuscript draft. All coauthors reviewed and edited the manuscript.

\section{CONFLICT OF INTEREST}

Authors declare no conflict of interest.

\section{REFERENCES}

Arroyo, J. M., Rigueiro, C., Rodríguez, R., Hampe, A., Valido, A., Rodríguez-SÁnchez, F., AND JORDANO, P. (2010). Isolation and characterization of 20 microsatellite loci for laurel species (Laurus, Lauraceae). American Journal of Botany, 97(5), e26-e30.

Barboza, K., Beretta, V., Kozub, P. C., Salinas, M. C., Morgenfeld, M. M., Galmarini, C. R., And Cavagnaro, P. F. (2018). Microsatellite analysis and marker development in garlic: Distribution in EST sequence, genetic diversity analysis, and marker transferability across Alliaceae. Molecular Genetics and Genomics, 293, 1091-1106.

Barboza, K., Salinas, M. C., Acuña, C. V., Bannoud, F., Beretta, V., García-Lampasona, S., Burba, J. L., Galmarini, C. R., and Cavagnaro, P. F. (2020). Assessment of genetic diversity and population structure in a garlic (Allium sativum L.) germplasm collection varying in bulb content of pyruvate, phenolics, and solids. Scientia Horticulturae, 261, 108900, doi: 10.1016/j.scienta.2019.108900.

Bradley, K. F., Rieger, M. A., and Collins, G. G. (1996). Classification of Australian garlic cultivars by DNA fingerprinting. Australian Journal of Experimental Agriculture, 36, 613-618.

Chand, S. K., Nanda, S., Rout, E., and Joshi, R. K. (2015). Mining, characterisation and validation of EST derived microsatellites from the transcriptome database of Allium sativum L. Bioinformation, 11, $145-150$.

Chen, S., Chen, W., Shen, X., Yang, Y., Qi, F., Liu, Y., And MenG, H. (2014). Analysis of the genetic diversity of garlic (Allium sativum L.) by simple sequence repeat and inter simple sequence repeat analysis and agro-morphological traits. Biochemical Systematics and Ecology, 55, 260-267.

Corander, J., And Marttinen, P. (2006). Bayesian identification of admixture events using multilocus molecular markers. Molecular Ecology, 15(10), 2833-2843.

Corander, J., Waldmann, P., and SillanpaA, M. J. (2003). Bayesian analysis of genetic differentiation between populations. Genetics, 163(1), 367-374.

Cunha, C. P., Hoogerheide, E. S., Zucchi, M. I., Monteiro, M., And Pinheiro, J. B. (2012). New microsatellite markers for garlic, Allium sativum (Alliaceae). American Journal of Botany, 99, e17-e19.

Cunha, C. P., Resende, F. V., Zucchi, M. I., And PInHeIRo, J. B. (2014). SSR-based genetic diversity and structure of garlic accessions from Brazil. Genetica, 142(5), 419-431.

Dice, L. R. (1945). Measures of the amount of ecologic association between species. Ecology, 26, 297-302.

Dumičić, G., Čagalu, M., Urlić, B., Runjić, M., And Goreta BAN, S. (2013). Yield components of 
introduced cultivars and local ecotypes of garlic (Allium sativum L.). Paper presented at the $48^{\text {th }}$ Croatian and $8^{\text {th }}$ International Symposium on Agriculture, Dubrovnik, Croatia, 349-352.

Dumičić, G., Pavić, Š., Ljubenkov, B., Urlić, B., Žanić, K., AND RAKO, A. (2014). Bulb yield components of garlic ecotypes from Adriatic region. Paper presented at the $49^{\text {th }}$ Croatian and $9^{\text {th }}$ International Symposium on Agriculture, Dubrovnik, Croatia, 310-314.

Earl, D. A., and Vonholdt, B. M. (2012). Structure HARVESTER: A website and program for visualising STRUCTURE output and implementing the Evanno method. Conservation Genetic Resources, 4(2), 359-361.

Egea, L. A., Mérida-García, R., Kilian, A., Hernanfez, P., AND Dorado, G. (2017). Assessment of genetic diversity and structure of large garlic (Allium sativum) Germplasm Bank, by Diversity Arrays Technology "Genotyping-by-Sequencing" Platform (DArTseq). Frontiers in Genetics, 8, 98, doi: 10.3389/ fgene.2017.00098.

Etoh, T., Noma, Y., Nishitarumizu, Y., and Makamoto, T. (1988). Seed productivity and germinability of various garlic clones collected in Soviet Central Asia. Memoirs of the Faculty of Agriculture, Kagoshima University, 24(1), 29-39.

Evanno, G., Regnaut, S., and Goudet, J. (2005). Detecting the number of clusters of individuals using the software STRUCTURE: A simulation study. Molecular Ecology, 14(8), 2611-2620.

Excoffier, L., AND Lischer, H. E. L. (2010). Arlequin suite ver 3.5: A new series of programs to perform population genetics analyses under Linux and Windows. Molecular Ecology Resources, 10, 564-567.

Excoffier, L., Smouse, P. E., And Quattro, J. M. (1992). Analysis of molecular variance inferred from metric distances among DNA haplotypes: Application to human mitochondrial DNA restriction sites. Genetics, 131, 479-491.

Faostat Database. Food And Agriculture Organization Of The United Nations. (2018). Rome, Italy: FAO. Retrieved from http://www.fao.org/faostat/en/\#data/ QC. (March 26, 2020).

Felsenstein, J. (1985). Confidence limits on phylogenesis: An approach using the bootstrap. Evolution, 39, 783-791.

Fischer, D., And Bachmann, K. (2000). Onion microsatellites for germplasm analysis and their use in assessing intra- and interspecific relatedness within the subgenus Rhizirideum. Theoretical and Applied Genetics, 101, 153-164.

Friesen, N., Smirnov, S. V., Shmakov, A. I., Harden, T., Oyuntsetseg, B., And Hurka, H. (2020). Allium species of section Rhizomatosa, early members of the Central Asian steppe vegetation. Flora, 263, 151536.

Fritsch, R. M., ANd Friesen, N. (2002). Evolution, domestication and taxonomy. In D. Rabinowitch and L. Currah (Eds), Allium crop science: Recent advances (pp. 5-30). Wallingford, UK: CAB International.

García-Lampasona, S. C., Asprelli, P., and Burba, J. L. (2012). Genetic analysis of a garlic (Allium sativum L.) germplasm collection from Argentina. Scientia Horticulturae, 138, 183-189.

García-Lampasona, S. C., Burba, J. L., and Simon, P. W. (2010). Molecular markers: Are they really useful to detect genetic variability in local garlic collections? The Americas Journal of Plant Science and Biotechnology, 4, 104-112.

García-Lampasona, S. C., Martínez, L., and Burba, J. L. (2003). Genetic diversity among selected Argentinean garlic clones (Allium sativum L.) using AFLP (amplified fragment length polymorphism). Euphytica, 132, 115-119.

Gimenez, M. D., and García-Lampasona, S. C. (2018). Before-after analysis of genetic and epigenetic markers in garlic: A 13-year experiment. Scientia Horticulturae, 240, 23-28.

Gimenez, M. D., Yañez-Santos, A. M., Paz, R. C., Quiroga, M. P., Marfil, C. F., Conci, V. C., And García-Lampasona, S. C. (2016). Assessment of genetic and epigenetic changes in virus-free garlic (Allium sativum L.) plants obtained by meristem culture followed by in vitro propagation. Plant Cell Reports, 35, 129-141.

Hammer, Ø., Harper, D. A. T., AND Ryan, P. D. (2001). PAST: Paleontological statistics software package for education and data analysis. Palaeontologia Electronica, 4(1), 9.

Hong, C. J., AND ETOH, T. (1996). Fertile clones of garlic (Allium sativum L.) abundant around the Tien Shan Mountains. Breeding Science, 46, 349-353.

Hosseinzadeh-Colagar, A., Haghighatnia, M. J., Amiri, Z., Mohadjerani, M., and Tafrihi, M. (2016). Microsatellite (SSR) amplification by PCR usually led to polymorphic bands: Evidence which shows replication slippage occurs in extend or nascent DNA strands. Molecular Biology Research Communications, 5(3), 167-174.

Hurlbert, S. H. (1971). The nonconcept of species diversity, a critique and alternative parameters. Ecology, 52, 577-586.

Ipek, M., IpeK, A., Almquist, S. G., And Simon, P. W. (2005). Demonstration of linkage and development of the first low-density genetic map of garlic, based on AFLP markers. Theoretical and Applied Genetics, 110, 228-236.

IPEK, M., IPEK, A., AND Simon, P. W. (2003). Comparison of AFLPs, RAPD markers, and isozymes for diversity assessment of garlic and detection of putative duplicates in germplasm collections. Journal of the American Society for Horticultural Science, 128, 246-252.

IpeK, M., IpeK, A., And Simon, P. W. (2006). Sequence homology of polymorphic AFLP markers in garlic (Allium sativum L.). Genome, 49, 1246-1255. 
IPEK, M., IPEK, A., AND Simon, P. W. (2008). Rapid characterisation of garlic clones with locus-specific DNA markers. Turkish Journal of Agriculture and Forestry, 32, 357-362.

Ipek, M., Sahin, N., IpeK, A., Cansev, A., And Simon, P. W. (2015). Development and validation of new SSR markers from expressed regions in the garlic genome. Scientia Agricola, 72(1), 41-46.

Jo, M. H., Ham, I. K., Moe, K. T., Kwon, S. W., Lu, F. H., Park, Y. J., Kim, W. S., Won, M. K., Kim, T. I., AND LEE, E. M. (2012). Classification of genetic variation in garlic (Allium sativum L) using SSR markers. Australian Journal of Crop Science, 6(4), 625-631.

Keller, E. R. J., Zanke, C. D., Senula, A., Breuing, A., Hardeweg, B., And Winkelmann, T. (2013). Comparing costs for different conservation strategies of garlic (Allium sativum L.) germplasm in genebanks. Genetic Resources and Crop Evolution, 60(3), 913-926.

Kopelman, N. M., Mayzel, J., Jakobsson, M., Rosenberg, N. A., And Mayrose, I. (2015). Clumpak: A program for identifying clustering modes and packaging population structure inferences across K. Molecular Ecology Resources, 15, 1179-1191.

Kumar, M., Rakesh Sharma, V., Kumar, V., Sirohi, U., Chaudhary, V., Sharma, S., Saripalli, G., Naresh, R. K., Kumar Yadav, H., and Sharma, S. (2019). Genetic diversity and population structure analysis of Indian garlic (Allium sativum L.) collection using SSR markers. Physiology and Molecular Biology of Plants, 5, 377-386.

Lazović, B., Klepo, T., Adakalić, M., ŠAtović, Z., Arbeiter, A. B., Hladnik, M., Strikić, F., Liber, Z., AND BANDELJ, D. (2018). Intra-varietal variability and genetic relationships among the homonymic East Adriatic olive (Olea europaea L.) varieties. Scientia Horticulturae, 236, 175-185.

Lee, G. A., Kwon, S. J., Park, Y. J., Lee, M. C., Kim, H. H., Lee, J. S., Lee, S. Y., GwaG, J. G., Kima, C. K., AND MA, K. H. (2011). Cross-amplification of SSR markers developed from Allium sativum to other Allium species. Scientia Horticulturae, 128, 401-407.

Lewontin, R. C. (1972). The apportionment on human diversity. Evolution Biology, 6, 381-398.

Li, Q. Q., Zhou, S. D., He, X. J., Yu, Y., Zhang, Y. C., AND WeI, X. Q. (2010). Phylogeny and biogeography of Allium (Amaryllidaceae: Allieae) based on nuclear ribosomal internal transcribed spacer and chloroplast rps16 sequences, focusing on the inclusion of species endemic to China. Annals of Botany, 106(5), 709-733.

Liu, T., Zeng, L., Zhu, S., Chen, X., Tang, Q., Mei, S., AND TANG, S. (2015). Large-scale development of expressed sequence tag-derived simple sequence repeat markers by deep transcriptome sequencing in garlic (Allium sativum L.). Molecular Breeding, 35, 204, doi: 10.1007/s11032-015-0399-x
Ma, K. H., Kwag, J. G., Zhao, W., Dixit, A., Lee, G. A., Kim, H. H., Chung, I. M., Kim, N. S., Lee, J. S., Ji, J. J., KIM, T. S., AND PARK, Y. J. (2009). Isolation and characteristics of eight novel polymorphic microsatellite loci from the genome of garlic (Allium sativum L). Scientia Horticulturae, 122(3), 355-361.

MaAss, H. I., AND KlaAs, M. (1995). Infraspecific differentiation of garlic (Allium sativum L.) by isozyme and RAPD markers. Theoretical and Applied Genetics, 91, 89-97.

Meena, R. K., Bhandari, M. S., And Ginwal, H. S. (2020). Usage of microsatellite markers for characterization of polyploids: A case study in reference to hexaploid bamboo species. Silvae Genetica, 69(1), 94-97.

Ovesná, J., Leišová-Svobodová, L., And KuČera, L. (2014). Microsatellite analysis indicates the specific genetic basis of Czech bolting garlic. Czech Journal of Genetics and Plant Breeding, 50, 226-234.

Ovesná, J., Mitrová, K., And KučEra, L. (2015). Garlic (A. sativum L.) alliinase gene family polymorphism reflects bolting types and cysteine sulphoxides content. BMC Genetics 16, 53, doi: 10.1186/s12863015-0214-z.

OžAnıć, S. (1955). Agriculture of Dalmatia in the past: Contributions to the history of Dalmatia agriculture. Croatia: Society of Agronomists NRHSplit Branch.

PAN, Y. B. (2006). Highly polymorphic microsatellite DNA markers for sugarcane germplasm evaluation and variety identity testing. Sugar Tech, 8, 246-256.

Paredes, C. M., Becerra, V. V., and Gonzalez, A. M. I. (2008). Low genetic diversity among garlic accessions detected using RAPD. Chilean Journal of Agricultural Research, 68, 3-12.

Peška, V., Mandáková, T., Ihradská, V., and Fajkus, J. (2019). Comparative dissection of three giant genomes: Allium cepa, Allium sativum, and Allium ursinum. International Journal of Molecular Sciences, 20(3), 733, doi: 10.3390/ijms20030733.

Poljuha, D., Kralu, I., ŠAtović, Z., Ban, D., Toth, N., Dumičić, G., Kereša, S., and Goreta Ban, S. (2018). Assessment of genetic diversity of garlic accessions from Croatia by SSR markers. Paper presented at the $4^{\text {th }}$ Congress of Croatian Geneticists with International Participation, Krk, Croatia, 58.

Pritchard, J. K., Stephens, M., And Donnelly, P. (2000). Inference of population structure using multilocus genotype data. Genetics, 155(2), 945-959.

Shannon, C. E., And Weaver, W. (1949). The mathematical theory of communication. Urbana, USA: University of Illinois Press.

STAVĚLíková, H. (2008). Morphological characteristics of garlic (Allium sativum L.) genetic resources collection - Information. Horticultural Science, 35, 130-135.

Trapnell, D. W., Hamrick, J. L., Parker, K. C., Braungart, K. W., AND Glenn, T.C.(2011). Evaluating 
the utility of microsatellites for investigations of autopolyploid taxa. Journal of Heredity, 102(4), 473-478.

Volk, G. M., Henk, A. D., and Richards, C. M. (2004). Genetic diversity among U. S. garlic clones as detected using AFLP methods. Journal of the American Society for Horticultural Science, 129, 559-569.

Walters, A. (2008). Production method and cultivar effects on garlic over-wintering survival, bulb quality, and yield. HortTechnology, 18(2), 286-289.

WANG, J. M., YANG, J. M., ZhU, J. H., JiA, Q. J., AND TAO, Y. Z. (2010). Assessment of genetic diversity by simple sequence repeat markers among forty elite varieties in the germplasm for malting barley breeding. Journal of Zheijang University Science B, 11(10), 792-800.

Wang, Z., Yu, G,. Shi, B., Wang, X., Qiang, H., And GAO, H. (2014). Development and characterization of Simple Sequence Repeat (SSR) markers based on RNA-sequencing of Medicago sativa and in silico mapping onto the M. truncatula genome. PLoS ONE, 9(3), e92029, doi: 10.1371/journal.pone.0092029.

Zhao, W. G., Chung, J. W., Lee, G. A., Ma, K. H., Kim, H. H., Kim, K. T., Chung, I. M., Lee, J. K., KIm, N. S., Kim, S. M., AND PARK, Y. J. (2011). Molecular genetic diversity and population structure of a selected core set in garlic and its relatives using novel SSR markers. Plant Breeding, 130, 46-54.

Received: December 15, 2020; accepted: March 31, 2021 


\section{SUPPLEMENTARY MATERIALS}

Table S1. List of accessions.

\begin{tabular}{|c|c|c|c|c|c|c|c|c|c|c|}
\hline $\begin{array}{l}\text { Accession } \\
\text { no. }\end{array}$ & $\begin{array}{l}\text { IPTPO } \\
\text { accession } \\
\text { ID }\end{array}$ & $\begin{array}{l}\text { Universal } \\
\text { accession } \\
\text { ID }\end{array}$ & Landrace & $\begin{array}{l}\text { Origin of } \\
\text { accession }\end{array}$ & Region & State & MLG & UPGMA & $\begin{array}{c}\text { Structure } \\
\text { K3 }\end{array}$ & $\begin{array}{l}\text { BAPS } \\
\text { K5 }\end{array}$ \\
\hline P1S01 & IJK18 $18^{\mathrm{NB}}$ & - & - & Vojnić & $\mathrm{P} 1$ & Croatia & G01 & B & B & B \\
\hline $\mathrm{P} 1 \mathrm{~S} 02$ & AFZ014 ${ }^{\mathrm{NB}}$ & - & Unski & Unčani & $\mathrm{P} 1$ & Croatia & G06 & A & A & A \\
\hline P1S03 & AFZ013 $3^{\mathrm{NB}}$ & - & Kerestinečki & Kerestinec & $\mathrm{P} 1$ & Croatia & U01 & $\mathrm{C}$ & $\mathrm{C}$ & $\mathrm{C}$ \\
\hline P1S04 & AFZ015 & - & Bjelovarski & Bjelovar & P1 & Croatia & U02 & A & A & A \\
\hline P1S05 & AGRE8 ${ }^{\mathrm{NB}}$ & - & - & $\begin{array}{l}\text { Sesvetski } \\
\text { Kraljevec }\end{array}$ & P1 & Croatia & U03 & B & B & B \\
\hline P1S06 & AGRE9 $^{\mathrm{NB}}$ & - & - & $\begin{array}{l}\text { Cerje } \\
\text { Lekeničko }\end{array}$ & $\mathrm{P} 1$ & Croatia & U04 & A & A & A \\
\hline P1S07 & AFZ011 ${ }^{\mathrm{NB}}$ & - & - & Bjelovar & $\mathrm{P} 1$ & Croatia & U05 & $\mathrm{C}$ & $\mathrm{C}$ & $\mathrm{C}$ \\
\hline P1S08 & IPT246 ${ }^{\mathrm{NB}}$ & - & $\begin{array}{l}\text { VGUK1,2- } \\
710\end{array}$ & Križevci & $\mathrm{P} 1$ & Croatia & U06 & A & A & A \\
\hline P1S09 & IPT249 & VEG00093 & $\begin{array}{l}\text { VGUK } \\
\text { Šokac }\end{array}$ & Cerić & P1 & Croatia & G02 & A & A & A \\
\hline P1S10 & IPT250 $0^{\mathrm{NB}}$ & - & VGUK675 & Bakovčice & $\mathrm{P} 1$ & Croatia & G02 & A & A & A \\
\hline P1S11 & IPT251 $1^{\mathrm{NB}}$ & - & $\begin{array}{l}\text { VGUK } \\
\text { Đakovački }\end{array}$ & Đakovo & $\mathrm{P} 1$ & Croatia & G02 & A & A & A \\
\hline $\mathrm{P} 1 \mathrm{~S} 12$ & IPT252 $2^{\mathrm{NB}}$ & - & $\begin{array}{l}\text { VGUK } \\
\text { Sremski }\end{array}$ & Srijem & $\mathrm{P} 1$ & Croatia & U07 & B & $\mathrm{BM}$ & B \\
\hline $\mathrm{P} 1 \mathrm{~S} 13$ & IPT272 & - & Bilogorski & $\begin{array}{l}\text { Donji } \\
\text { Mosti }\end{array}$ & $\mathrm{P} 1$ & Croatia & U08 & $\mathrm{C}$ & $\mathrm{C}$ & $\mathrm{C}$ \\
\hline P1S14 & IPT273 $3^{\mathrm{NB}}$ & - & Mraclinski & Mraclin & $\mathrm{P} 1$ & Croatia & U09 & B & B & B \\
\hline P1S15 & IPT274 & - & Kerestinečki & Kerestinec & $\mathrm{P} 1$ & Croatia & G07 & $\mathrm{C}$ & $\mathrm{C}$ & $\mathrm{C}$ \\
\hline P1S16 & IPT275 & - & Unski & Unčani & $\mathrm{P} 1$ & Croatia & G07 & $\mathrm{C}$ & $\mathrm{C}$ & $\mathrm{C}$ \\
\hline P2S17 & $\mathrm{IJK} 7^{\mathrm{NB}}$ & - & Tinjanski & Tinjan & $\mathrm{P} 2$ & Croatia & G08 & A & A & A \\
\hline $\mathrm{P} 2 \mathrm{~S} 18$ & IPTO10 & VEG00095 & $\begin{array}{l}\text { Domaći } \\
\text { ozimi crveni }\end{array}$ & Pazin & $\mathrm{P} 2$ & Croatia & U10 & $\mathrm{D}$ & $\mathrm{C}$ & $\mathrm{D}$ \\
\hline $\mathrm{P} 2 \mathrm{~S} 19$ & IPTO11 $^{\text {B }}$ & VEG00096 & $\begin{array}{l}\text { Domaći } \\
\text { ozimi }\end{array}$ & Kaštelir & $\mathrm{P} 2$ & Croatia & G03 & A & A & A \\
\hline $\mathrm{P} 2 \mathrm{~S} 20$ & IPTO12 & VEG00097 & $\begin{array}{l}\text { Domaći } \\
\text { ozimi with } \\
\text { stalk }\end{array}$ & Kaštelir & $\mathrm{P} 2$ & Croatia & G03 & A & A & A \\
\hline $\mathrm{P} 2 \mathrm{~S} 21$ & IPTO13 $^{\mathrm{B}}$ & VEG00098 & $\begin{array}{l}\text { Istarski } \\
\text { crveni }\end{array}$ & Lindar & $\mathrm{P} 2$ & Croatia & G03 & A & A & A \\
\hline $\mathrm{P} 2 \mathrm{~S} 22$ & $\mathrm{IPTO}^{\mathrm{NB}}$ & VEG00094 & Domaći jari & Tinjan & $\mathrm{P} 2$ & Croatia & U11 & A & A & A \\
\hline $\mathrm{P} 2 \mathrm{~S} 23$ & IPTO15 ${ }^{\mathrm{NB}}$ & VEG00099 & Istarski bijeli & Pazin & $\mathrm{P} 2$ & Croatia & $\mathrm{U} 12$ & A & A & $\mathrm{A}$ \\
\hline $\mathrm{P} 2 \mathrm{~S} 24$ & IPTO16 & VEG00100 & $\begin{array}{l}\text { Istarski } \\
\text { domaći }\end{array}$ & Ograde & $\mathrm{P} 2$ & Croatia & U13 & A & A & A \\
\hline $\mathrm{P} 2 \mathrm{~S} 25$ & IPTO17 ${ }^{\mathrm{NB}}$ & VEG00101 & Istarski bijeli & Ograde & $\mathrm{P} 2$ & Croatia & U14 & A & A & A \\
\hline $\mathrm{P} 2 \mathrm{~S} 26$ & IPTO19 & VEG00102 & Brgujski & $\begin{array}{l}\text { Brgud } \\
\text { (Opatija) }\end{array}$ & P2 & Croatia & U15 & $\mathrm{D}$ & $\mathrm{C}$ & $\mathrm{D}$ \\
\hline
\end{tabular}


Table S1. (Continued)

\begin{tabular}{|c|c|c|c|c|c|c|c|c|c|c|}
\hline $\begin{array}{l}\text { Accession } \\
\text { no. }\end{array}$ & $\begin{array}{l}\text { IPTPO } \\
\text { accession } \\
\text { ID }\end{array}$ & $\begin{array}{l}\text { Universal } \\
\text { accession } \\
\text { ID }\end{array}$ & Landrace & $\begin{array}{l}\text { Origin of } \\
\text { accession }\end{array}$ & Region & State & MLG & UPGMA & $\begin{array}{c}\text { Structure } \\
\text { K3 }\end{array}$ & $\begin{array}{c}\text { BAPS } \\
\text { K5 }\end{array}$ \\
\hline P2S27 & IPTO20 & VEG00103 & Brsečki & Brseč & $\mathrm{P} 2$ & Croatia & U16 & A & A & A \\
\hline P2S28 & IPT224 $4^{\mathrm{NB}}$ & VEG00104 & - & Ližnjan & $\mathrm{P} 2$ & Croatia & U17 & A & $\mathrm{AM}$ & A \\
\hline P2S29 & IPT338 & - & Istarski bijeli & Lindar & $\mathrm{P} 2$ & Croatia & U18 & A & A & A \\
\hline P2S30 & IPT339 & - & Music & Lindar & $\mathrm{P} 2$ & Croatia & U19 & $\mathrm{X}$ & $\mathrm{CM}$ & $\mathrm{D}$ \\
\hline P2S31 & IPT341 ${ }^{\mathrm{B}}$ & - & $\begin{array}{l}\text { Istarski } \\
\text { crveni }\end{array}$ & Pićan & $\mathrm{P} 2$ & Croatia & U20 & A & A & A \\
\hline $\mathrm{P} 2 \mathrm{~S} 32$ & IPT342 & - & Mješavina & Tinjan & $\mathrm{P} 2$ & Croatia & G04 & A & A & A \\
\hline P2S33 & IPT343 & - & $\begin{array}{l}\text { Istarski } \\
\text { crveni }\end{array}$ & Gračišće & $\mathrm{P} 2$ & Croatia & G04 & A & A & A \\
\hline P2S34 & IPT344 ${ }^{\mathrm{NB}}$ & - & Istarski bijeli & Gračišće & $\mathrm{P} 2$ & Croatia & G04 & A & A & A \\
\hline P2S35 & IPT345 & - & $\begin{array}{l}\text { Istarski } \\
\text { crveni }\end{array}$ & Beram & $\mathrm{P} 2$ & Croatia & U21 & A & A & A \\
\hline $\mathrm{P} 2 \mathrm{~S} 36$ & IPT347 & - & $\begin{array}{l}\text { Istarski } \\
\text { crveni } \\
\text { (with stalk) }\end{array}$ & Oprtalj & $\mathrm{P} 2$ & Croatia & U22 & A & A & A \\
\hline P2S37 & IPT348 & - & $\begin{array}{l}\text { Istarski } \\
\text { crveni } \\
\text { (without } \\
\text { stalk) }\end{array}$ & Oprtalj & $\mathrm{P} 2$ & Croatia & U23 & $\mathrm{D}$ & $\mathrm{C}$ & $\mathrm{D}$ \\
\hline P2S38 & IPT349 & - & $\begin{array}{l}\text { Istarski } \\
\text { crveni (with } \\
\text { stalk) }\end{array}$ & Oprtalj & $\mathrm{P} 2$ & Croatia & $\mathrm{U} 24$ & A & A & A \\
\hline P3S39 & $\mathrm{IJK} 3^{\mathrm{NB}}$ & VEG00223 & - & Zmijavci & P3 & Croatia & $\mathrm{U} 25$ & A & A & A \\
\hline P3S40 & $\mathrm{IJK} 4^{\mathrm{NB}}$ & VEG00224 & - & $\begin{array}{l}\text { Rastok } \\
\text { (Vrgorac) }\end{array}$ & P3 & Croatia & G09 & B & B & B \\
\hline P3S41 & IJK8 $8^{\mathrm{NB}}$ & VEG00225 & - & Kurtovići & $\mathrm{P} 3$ & Croatia & $\mathrm{U} 26$ & A & A & A \\
\hline P3S42 & IJK $9^{\mathrm{NB}}$ & VEG00227 & - & $\begin{array}{l}\text { Obrovac } \\
\text { Sinjski }\end{array}$ & P3 & Croatia & G05 & A & A & A \\
\hline P3S43 & $\mathrm{IJK} 10^{\mathrm{NB}}$ & VEG00226 & - & Stija & P3 & Croatia & $\mathrm{U} 27$ & A & A & A \\
\hline P3S44 & IJK13 $3^{\mathrm{NB}}$ & VEG00229 & - & $\begin{array}{l}\text { Primorski } \\
\text { dolac }\end{array}$ & P3 & Croatia & G08 & A & A & A \\
\hline P3S45 & IJK14 ${ }^{\mathrm{B}}$ & VEG00230 & - & Trnbusi 1 & P3 & Croatia & G05 & A & A & A \\
\hline P3S46 & IJK17 $7^{\mathrm{NB}}$ & VEG00231 & - & $\begin{array}{l}\text { Opuzen } \\
\text { (Raba) }\end{array}$ & P3 & Croatia & U28 & B & B & B \\
\hline P3S47 & IJK19 $19^{\mathrm{NB}}$ & VEG00232 & - & Metković & P3 & Croatia & G01 & B & B & B \\
\hline P3S48 & $\mathrm{IJK} 20^{\mathrm{NB}}$ & VEG00236 & - & Trnbusi 2 & $\mathrm{P} 3$ & Croatia & G01 & B & B & B \\
\hline P3S49 & IJK22 & VEG00234 & - & $\begin{array}{l}\text { Rama } \\
\text { (Vinjani g.) }\end{array}$ & P3 & Croatia & G05 & A & A & A \\
\hline P3S50 & $\mathrm{IJK} 23^{\mathrm{NB}}$ & VEG00235 & - & Kijevo & P3 & Croatia & U29 & A & A & A \\
\hline P3S51 & $\mathrm{IJK} 24^{\mathrm{NB}}$ & VEG00236 & - & Golubić 2 & P3 & Croatia & U30 & $\mathrm{C}$ & $\mathrm{C}$ & $\mathrm{C}$ \\
\hline P3S52 & $\mathrm{IJK} 25^{\mathrm{NB}}$ & VEG00237 & - & Golubić 1 & P3 & Croatia & G01 & $\mathrm{B}$ & B & B \\
\hline
\end{tabular}


Table S1. (Continued)

\begin{tabular}{|c|c|c|c|c|c|c|c|c|c|c|}
\hline $\begin{array}{l}\text { Accession } \\
\text { no. }\end{array}$ & $\begin{array}{l}\text { IPTPO } \\
\text { accession } \\
\text { ID }\end{array}$ & $\begin{array}{l}\text { Universal } \\
\text { accession } \\
\text { ID }\end{array}$ & Landrace & $\begin{array}{l}\text { Origin of } \\
\text { accession }\end{array}$ & Region & State & MLG & UPGMA & $\begin{array}{c}\text { Structure } \\
\text { K3 }\end{array}$ & $\begin{array}{c}\text { BAPS } \\
\text { K5 }\end{array}$ \\
\hline P3S53 & $\mathrm{IJK} 26^{\mathrm{NB}}$ & VEG00130 & $\begin{array}{l}\text { Ljubitovački } \\
\text { šarac }\end{array}$ & Ljubitovica & $\mathrm{P} 3$ & Croatia & U31 & A & AM & AM \\
\hline P3S54 & $\mathrm{IJK} 27^{\mathrm{B}}$ & VEG00238 & - & $\begin{array}{l}\text { Unešić } \\
\text { Plameni }\end{array}$ & $\mathrm{P} 3$ & Croatia & U32 & $\mathrm{D}$ & $\mathrm{CM}$ & $\mathrm{D}$ \\
\hline P3S55 & IJK28 & - & - & Unešić Jaki & P3 & Croatia & U33 & B & B & B \\
\hline P3S56 & AFZ024 & - & Bruški 1 & Bruška & $\mathrm{P} 3$ & Croatia & U34 & B & B & B \\
\hline P3S57 & $\mathrm{AFZ} 025^{\mathrm{NB}}$ & - & Lisičićki 1 & Lisičić & P3 & Croatia & G01 & B & B & B \\
\hline P3S58 & AFZ026 ${ }^{\mathrm{NB}}$ & - & Rodaljički & Rodaljice & P3 & Croatia & U35 & B & B & B \\
\hline P3S59 & VEG00010 NB & VEG00010 & $\begin{array}{l}\text { Brgudski } \\
\text { ozimi syn. } \\
\text { Benkovački }\end{array}$ & Brgud & P3 & Croatia & G01 & B & B & B \\
\hline P3S60 & IPT268 & - & Cabrunski & Cabrun & P3 & Croatia & U36 & B & B & B \\
\hline P3S61 & IPT269 & - & Bruški & Brusje & $\mathrm{P} 3$ & Croatia & U37 & B & B & B \\
\hline P3S62 & IPT270 ${ }^{\mathrm{NB}}$ & - & Lisički & Lisje & P3 & Croatia & G10 & B & B & B \\
\hline P3S63 & IPT271 ${ }^{\mathrm{NB}}$ & & Rodaljički & Rodaljice & $\mathrm{P} 3$ & Croatia & G10 & B & B & B \\
\hline P3S64 & IPT276 ${ }^{\mathrm{NB}}$ & - & $\begin{array}{l}\text { Brgudski } \\
\text { ozimi syn. } \\
\text { Benkovački } 1\end{array}$ & Brgud & $\mathrm{P} 3$ & Croatia & U38 & B & $\mathrm{BM}$ & B \\
\hline P4S65 & B_2 & $0033^{*}$ & Chinês real & China & $\mathrm{P} 4$ & Brazil & U39 & $\mathrm{E}$ & $\mathrm{CM}$ & E \\
\hline P4S66 & B_5 & $0077^{*}$ & Peruano & Peru & $\mathrm{P} 4$ & Brazil & U40 & A & $\mathrm{AM}$ & $\mathrm{AM}$ \\
\hline P4S67 & B_9 & 0089* & Ugarte & Brazil & $\mathrm{P} 4$ & Brazil & U41 & $\mathrm{E}$ & $\mathrm{CM}$ & $\mathrm{E}$ \\
\hline P4S68 & IPT177 & $\begin{array}{l}\text { VEG00118/ } \\
\text { W610735** }\end{array}$ & B92-22 & Bulgaria & P4 & Bulgaria & U42 & B & B & B \\
\hline P4S69 & IPT182 & $\begin{array}{l}\text { VEG00124/ } \\
\text { PI493116** }\end{array}$ & 174 & $\begin{array}{l}\text { Czech } \\
\text { Republic }\end{array}$ & U43 & $\begin{array}{l}\text { Czech } \\
\text { Republic }\end{array}$ & U43 & $\mathrm{D}$ & $\mathrm{C}$ & $\mathrm{D}$ \\
\hline P4S70 & $\mathrm{IJK} 2^{\mathrm{NB}}$ & & - & $\begin{array}{l}\text { Pinčić } \\
\text { (Skadar) }\end{array}$ & $\mathrm{P} 4$ & Montenegro & G09 & B & B & B \\
\hline P4S71 & IPT181 $^{\mathrm{B}}$ & $\begin{array}{l}\text { VEG00123/ } \\
\text { PI497945)** }\end{array}$ & - & Poland & $\mathrm{P} 4$ & Poland & U44 & $\mathrm{C}$ & $\mathrm{C}$ & $\mathrm{C}$ \\
\hline P4S72 & IPT185 & $\begin{array}{l}\text { VEG00126/ } \\
\text { PI540351** }\end{array}$ & $0525-85-76$ & Poland & $\mathrm{P} 4$ & Poland & U45 & $\mathrm{C}$ & $\mathrm{C}$ & $\mathrm{C}$ \\
\hline P4S73 & IPT179 & $\begin{array}{l}\text { VEG00128/ } \\
\text { PI383817** }\end{array}$ & Domasen & Serbia & $\mathrm{P} 4$ & Serbia & U46 & A & A & A \\
\hline P4S74 & IPT189 & VEG00129 & - & Subotica & $\mathrm{P} 4$ & Serbia & U47 & B & B & B \\
\hline P4S75 & AGRE11 ${ }^{\mathrm{NB}}$ & & - & $\begin{array}{l}\text { Semenarna } \\
\text { Ljubljana }\end{array}$ & $\mathrm{P} 4$ & Slovenia & G06 & A & A & A \\
\hline P4S76 & IPT186 ${ }^{\mathrm{NB}}$ & $\begin{array}{l}\text { VEG00119/ } \\
\text { PI615422** }\end{array}$ & $\begin{array}{l}\text { Blanco de } \\
\text { Huelma } \\
\text { Zamora I }\end{array}$ & Spain & $\mathrm{P} 4$ & Spain & U48 & B & B & B \\
\hline P4S77 & IPT188 & $\begin{array}{l}\text { VEG00122/ } \\
\text { PI3497951** }\end{array}$ & Kisswani & Syria & $\mathrm{P} 4$ & Syria & U49 & $X$ & $\mathrm{CM}$ & DM \\
\hline P4S78 & IPT180 ${ }^{\mathrm{NB}}$ & $\begin{array}{l}\text { VEG00125/ } \\
\text { PI3515971** }\end{array}$ & Chet's & USA & $\mathrm{P} 4$ & USA & G01 & B & B & B \\
\hline
\end{tabular}


Table S1. (Continued)

\begin{tabular}{|c|c|c|c|c|c|c|c|c|c|c|}
\hline $\begin{array}{l}\text { Accession } \\
\text { no. }\end{array}$ & $\begin{array}{l}\text { IPTPO } \\
\text { accession } \\
\text { ID }\end{array}$ & $\begin{array}{l}\text { Universal } \\
\text { accession } \\
\text { ID }\end{array}$ & Landrace & $\begin{array}{l}\text { Origin of } \\
\text { accession }\end{array}$ & Region & State & MLG & UPGMA & $\begin{array}{c}\text { Structure } \\
\text { K3 }\end{array}$ & $\begin{array}{c}\text { BAPS } \\
\text { K5 }\end{array}$ \\
\hline P4S79 & IPT187 & $\begin{array}{l}\text { VEG00120/ } \\
\text { W612832** }\end{array}$ & 870825 & USA & $\mathrm{P} 4$ & USA & U50 & A & AM & A \\
\hline P4S80 & IPT178 & $\begin{array}{l}\text { VEG00127/ } \\
\text { PI576914** }\end{array}$ & UO86 & Uzbekistan & $\mathrm{P} 4$ & Uzbekistan & U51 & $\mathrm{D}$ & $\mathrm{C}$ & $\mathrm{D}$ \\
\hline
\end{tabular}

MLG, multilocus genotype; NPGS, National Plant Germplasm System.

Accession No.: Accession number; IPTPO Accession ID: Institute of Agriculture and Tourism Collection ID (flowering behaviour ( ${ }^{\mathrm{B}}$ - bolting, $\mathrm{NB}$ - non-bolting); Universal Accession ID: CPGRD (Croatian Plant Genetic Resources Database; cpgrd.hapih.hr), CENARGEN, Embrapa, Brazil*, and GRIN, NPGS, USA** Collection ID; Landrace: traditional name or name listed in the collection; Origin of Accession: original collecting site; Region: Region of origin (P1 - continental Croatia, P2 - Istria, P3 -Dalmatia, P4 Foreign accessions); State: State of origin; $M L G$ : Multilocus genotype (G group of identical accessions, U - unique genotype); UPGMA: Cluster on UPGMA tree (X - separate lineage); Structure K3: Cluster based on STRUCTURE analysis at $K=3(\mathrm{M}-$ accession of mixed origin: the proportion of membership lower than 0.75 in any cluster); BAPS K5: Cluster based on BAPS analysis at $K=5$ (M - accession of mixed origin: the proportion of membership lower than 0.75 in any cluster).

Table S2. Number of SSR electropherogram peaks per marker per number of accessions observed in the set of 80 accessions.

\begin{tabular}{lccccc}
\hline & \multicolumn{5}{c}{ Number of peaks } \\
\cline { 2 - 6 } Locus & 1 & 2 & 3 & 4 & 5 \\
\hline AS2655 & 33 & 38 & 7 & 0 & 2 \\
AS449 & 27 & 51 & 1 & 1 & 0 \\
AS5944 & 13 & 62 & 4 & 1 & 0 \\
AS623 & 37 & 43 & 0 & 0 & 0 \\
AS6389 & 12 & 68 & 0 & 0 & 0 \\
AS739 & 1 & 78 & 0 & 1 & 0 \\
AS96 & 0 & 78 & 1 & 0 & 0 \\
Asa14 & 4 & 44 & 23 & 2 & 0 \\
GB-ASM-040 & 12 & 64 & 3 & 1 & 0 \\
GB-ASM-053 & 4 & 26 & 49 & 1 & 0 \\
GB-ASM-059 & 8 & 68 & 3 & 1 & 0 \\
GB-ASM-072 & 36 & 27 & 14 & 0 & 0 \\
GB-ASM-080 & 52 & 28 & 0 & 0 & 0 \\
\hline
\end{tabular}

SSR, simple sequence repeat.

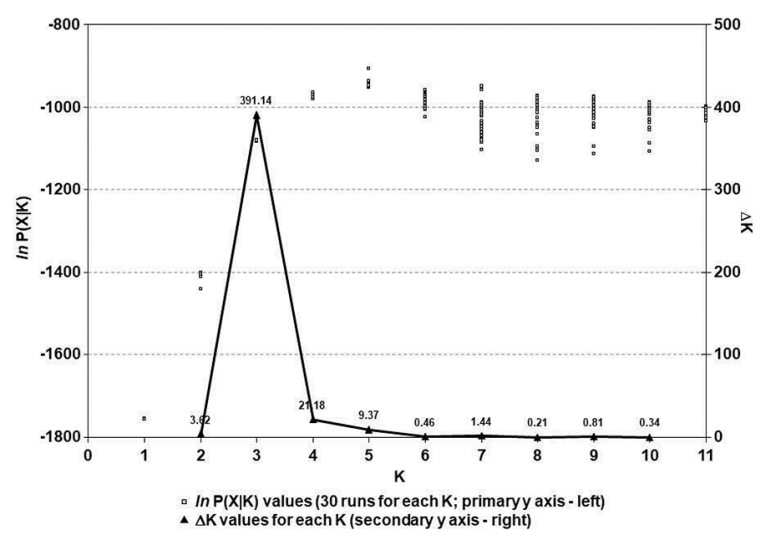

Figure S1. Inference of the most likely number of clusters based on the results of STRUCTURE by analysing SSR data of 80 garlic accessions. SSR, simple sequence repeat. 